Supporting Information

\title{
Multicolor fluorescence based on FRET regulated by functional peptides to screen high metastatic potential cancer cells
}

\author{
Ying Wen, ${ }^{\dagger}$ Fangjun Huo, ${ }^{\ddagger}$ Junping Wang ${ }^{\dagger}$ and Caixia Yin ${ }^{\dagger}, *$ \\ † Key Laboratory of Chemical Biology and Molecular Engineering of Ministry of \\ Education, Key Laboratory of Materials for Energy Conversion and Storage of Shanxi \\ Province, Institute of Molecular Science, Shanxi University, Taiyuan 030006, China. \\ C.X. Yin, E-mail: yincx@sxu.edu.cn, Tel/Fax: +86-351-7011022. \\ ¥ Research Institute of Applied Chemistry, Shanxi University, Taiyuan 030006, China.
}

\section{Contents}

1. The synthesis route of probe

2. Characteristics of peptide and probe

3. Absorption spectra of probe

4. The detection limit of probe for $\mathrm{H}_{2} \mathrm{O}_{2}$

5. The detection limit of probe for MMP2

6. Cytotoxicity of probe

7. Additional cell imaging of probe for monitoring $\mathrm{H}_{2} \mathrm{O}_{2}$

8. References 


\section{The synthesis route of probe.}

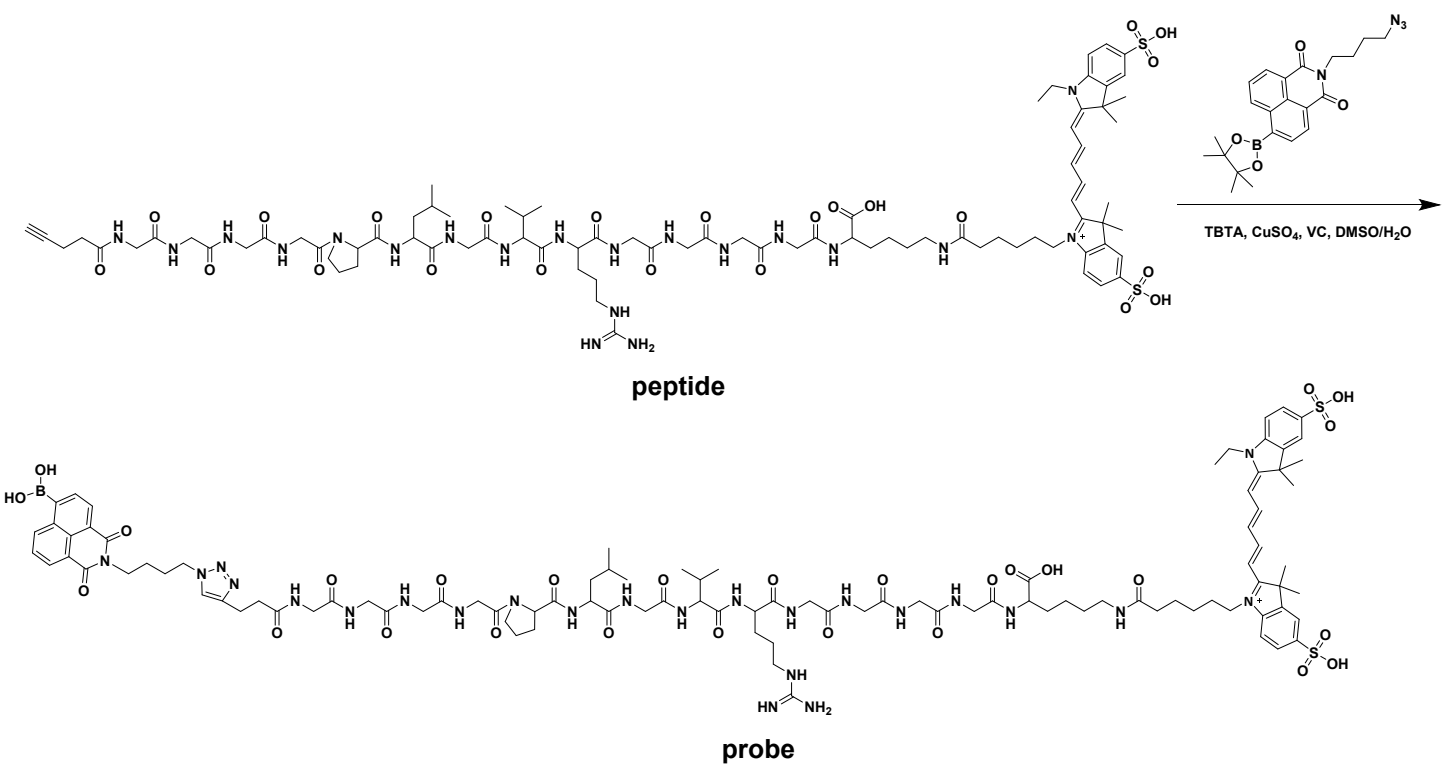

Scheme 1. The synthetic route of probe.

\section{Characteristics of peptide and probe}

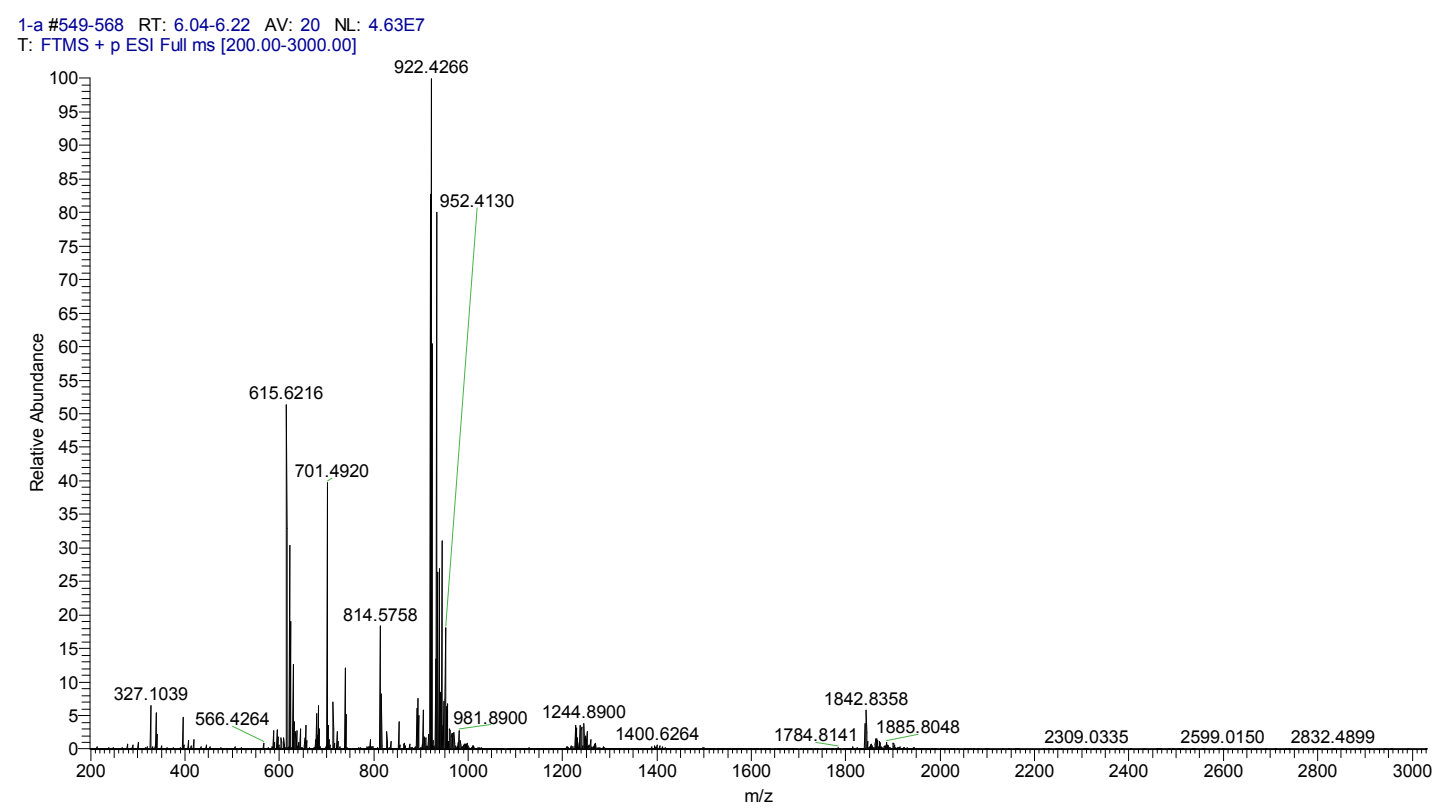

Figure S1. The HR-MS of peptide: calc. for $\mathrm{C}_{84} \mathrm{H}_{123} \mathrm{~N}_{20} \mathrm{O}_{23} \mathrm{~S}_{2}{ }^{+}[\mathrm{M}+\mathrm{H}]^{2+}$ 922.4295; found 922.4266 . 


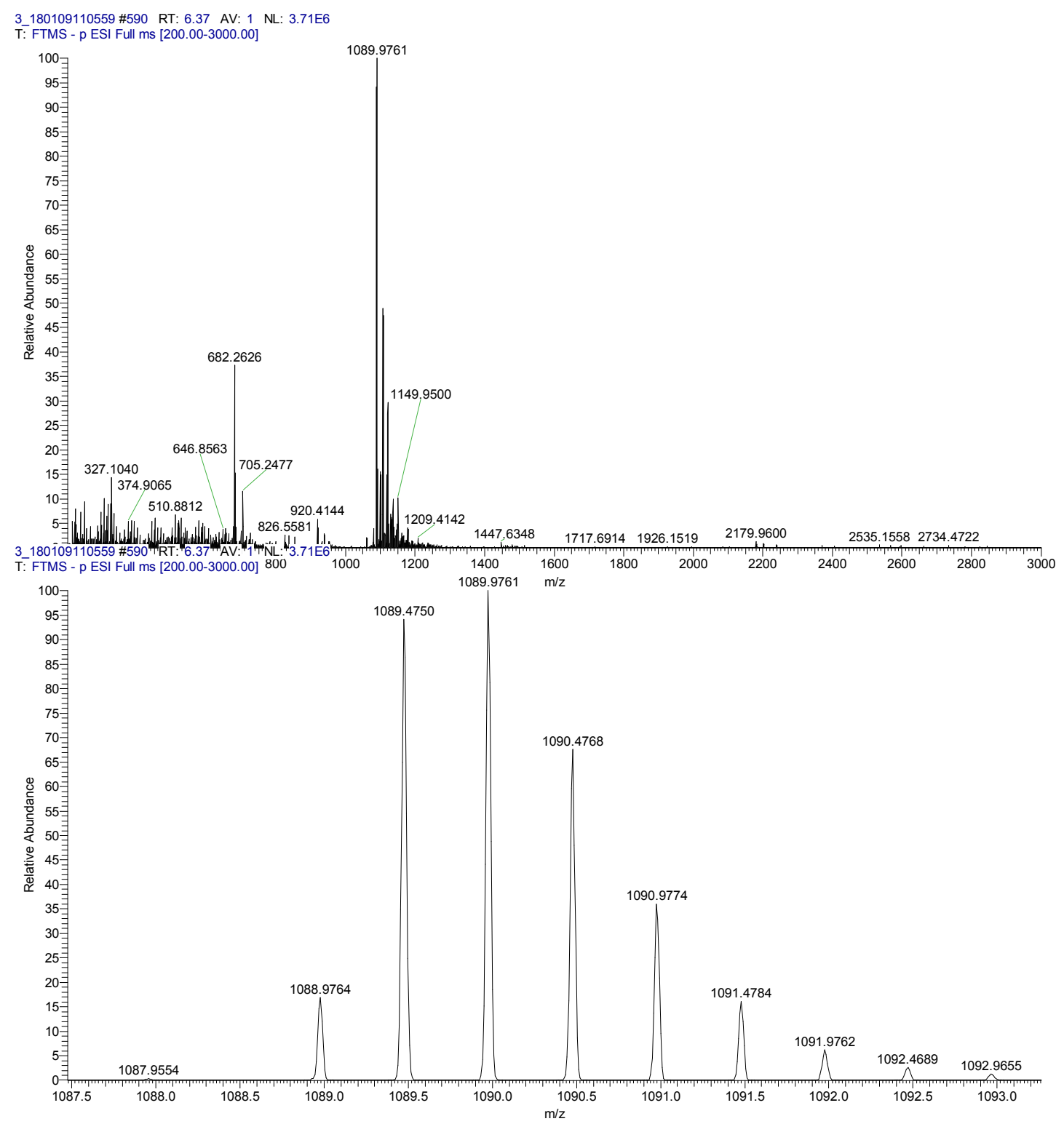

Figure S2. The HR-MS of probe: calc. for $\mathrm{C}_{100} \mathrm{H}_{138} \mathrm{BN}_{24} \mathrm{O}_{27} \mathrm{~S}_{2}{ }^{+}[\mathrm{M}-3 \mathrm{H}]^{2+}$ 1089.4732; found 1089.4750 .

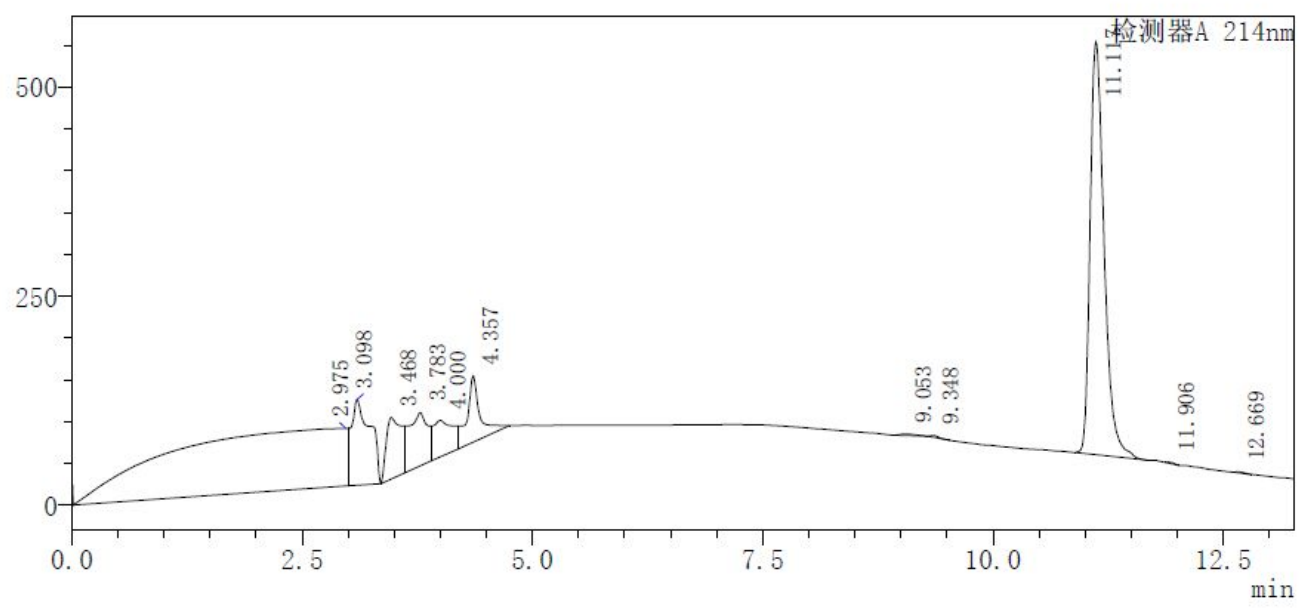


Figure S3. Representative chromatogram of probe (the monitoring wavelength: 220 $\mathrm{nm}$; the purity $>95 \%$ ).

\section{Absorption spectra of probe}

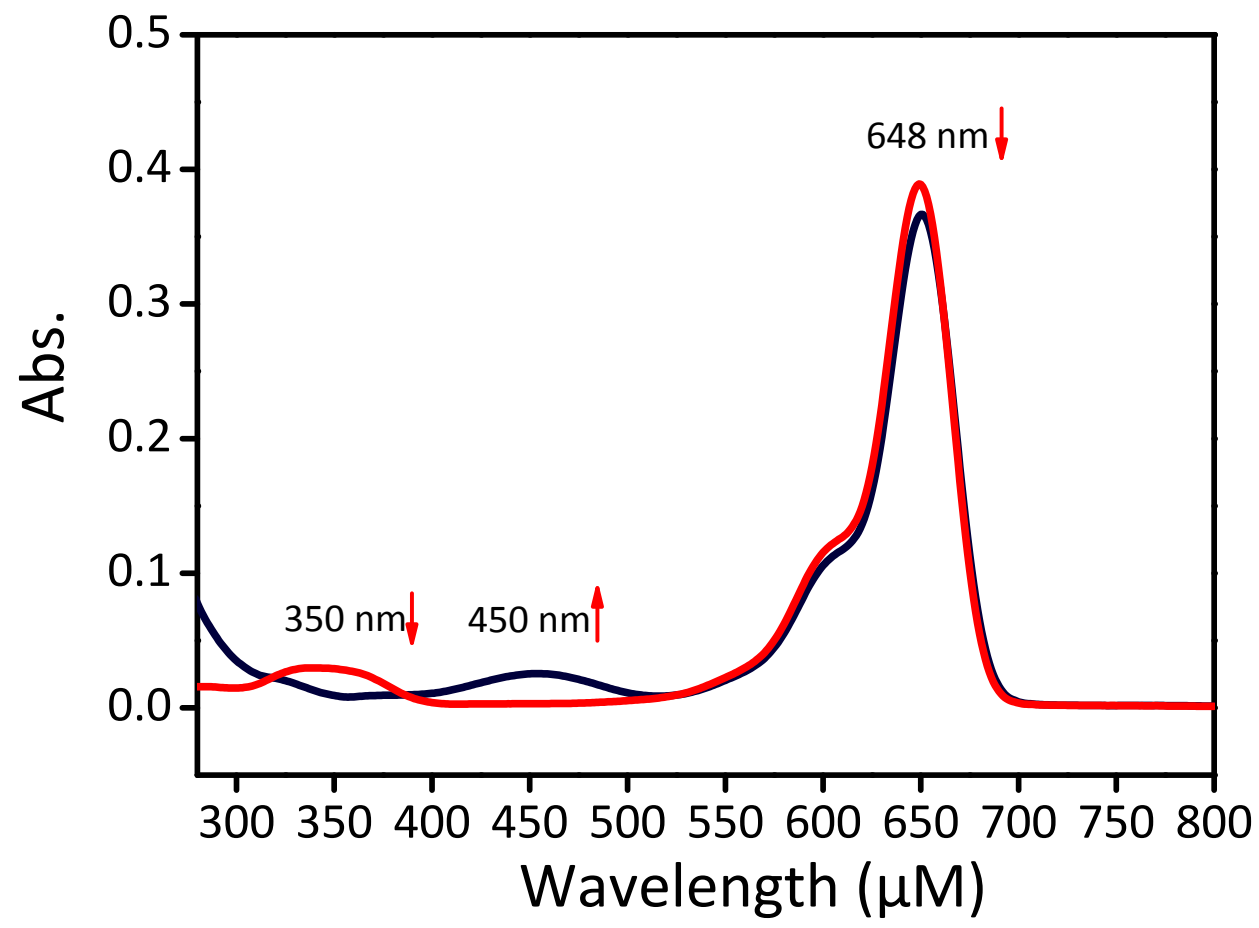

Figure S4. Absorption spectra of probe $(2 \mu \mathrm{M})$ without (red line) or with (black line) $\mathrm{H}_{2} \mathrm{O}_{2}$ (1 $\mathrm{mM}$ in PBS, $1 \%$ DMSO).

4. The detection limit of probe for $\mathrm{H}_{2} \mathrm{O}_{2}$ 


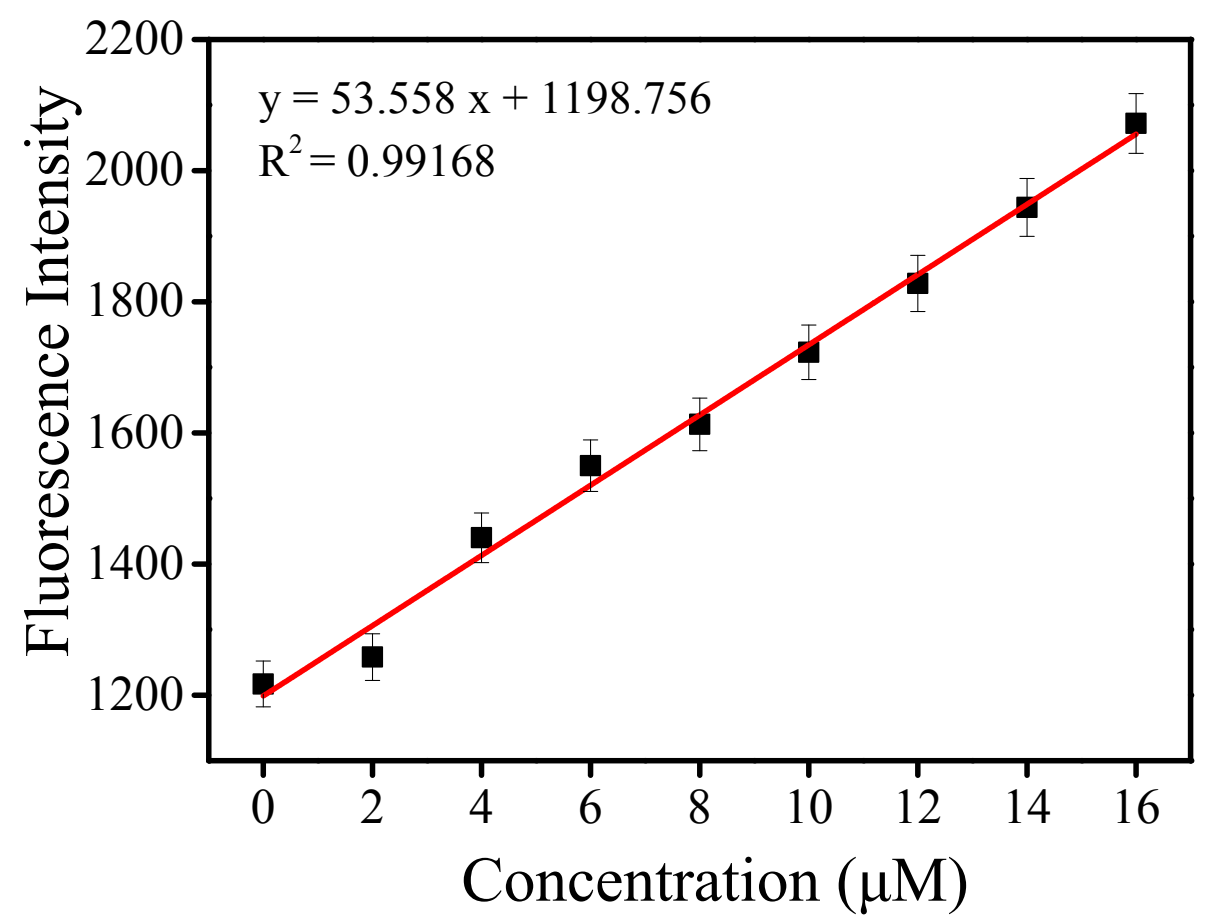

Figure S5 Plot of fluorescence intensity at $672 \mathrm{~nm}\left(F_{672}\right)$ for probe $(2 \mu \mathrm{M}) v s\left[\mathrm{H}_{2} \mathrm{O}_{2}\right]$ in the range of $0 \sim 16 \mu \mathrm{M}$ in PBS ( $\mathrm{pH}$ 7.2). Each data was acquired $2 \mathrm{~h}$ after the addition of $\mathrm{H}_{2} \mathrm{O}_{2}$ at $37{ }^{\circ} \mathrm{C}, \lambda_{\text {ex }}=450 \mathrm{~nm}$. The detection limit $(0.539 \mu \mathrm{M})$ of probe for $\mathrm{H}_{2} \mathrm{O}_{2}$ was calculated with the equation $3 \sigma / k$; where $\sigma$ is the standard deviation of blank measurement; $k$ is the slop the calibration curve in this figure.

Table S1: The detection limit examples of established $\mathrm{H}_{2} \mathrm{O}_{2}$ probes.

\begin{tabular}{|c|c|}
\hline Some examples & Detection limit \\
\hline Anal. Chem.,2017, 89, 552-555 ${ }^{1}$ & $2.1 \mu \mathrm{M}$ \\
\hline Anal. Chem.,2019, 91, 6902-6909 2 & $0.025 \mu \mathrm{M}$ \\
\hline Chem. Commun., 2017, 53, 3701-3704 ${ }^{3}$ & $0.22 \mu \mathrm{M}$ \\
\hline Analyst, $2019,144,3643-3648^{4}$ & $0.14 \mu \mathrm{M}$ \\
\hline Anal. Chem., 2019, 91, 1203-1210 5 & $0.050 \mu \mathrm{M}$ \\
\hline Chem. Asian J., 2016, 11, 818-828 ${ }^{6}$ & $2.0 \mu \mathrm{M}$ \\
\hline Chem. Sci., 2016, 7, 6153-6159 7 & $0.08 \mu \mathrm{M}, 0.12 \mu \mathrm{M}$ \\
\hline This paper & 0.539 \\
\hline
\end{tabular}

\section{The detection limit of probe for MMP2}




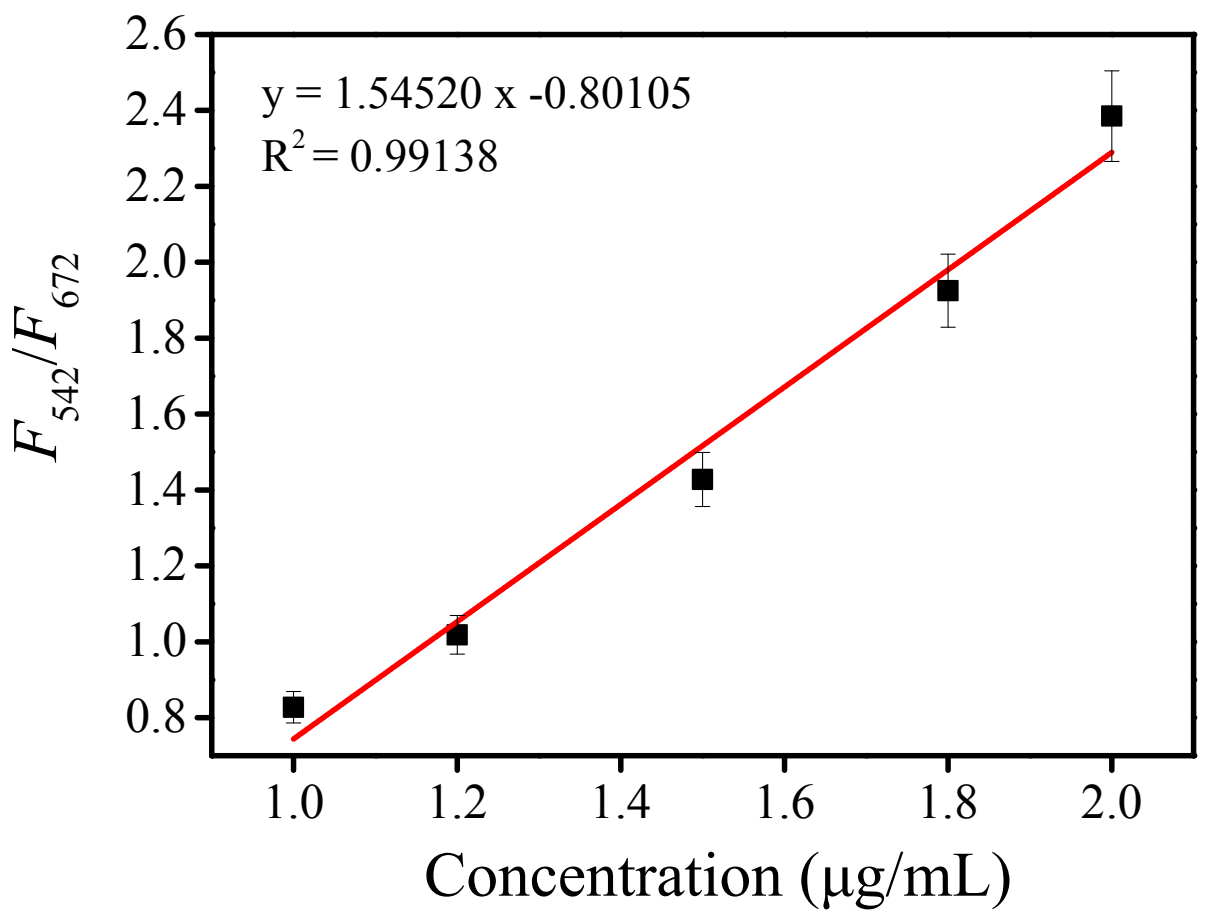

Figure S6 Plot of $F_{542} / F_{672}$ for probe ( $2 \mu \mathrm{M}$, mixed up $500 \mu \mathrm{M} \mathrm{H} \mathrm{H}_{2} \mathrm{O}_{2}$ for 120 min) $v s$ [MMP2] in the range of 1.0 2.0 $\mu \mathrm{g} / \mathrm{mL}$ in PBS (pH 7.2). Each data was acquired $1 \mathrm{~h}$ after MMP2 addition at $25^{\circ} \mathrm{C}, \lambda_{\mathrm{ex}}=450 \mathrm{~nm}$.

\section{Cytotoxicity of probe}




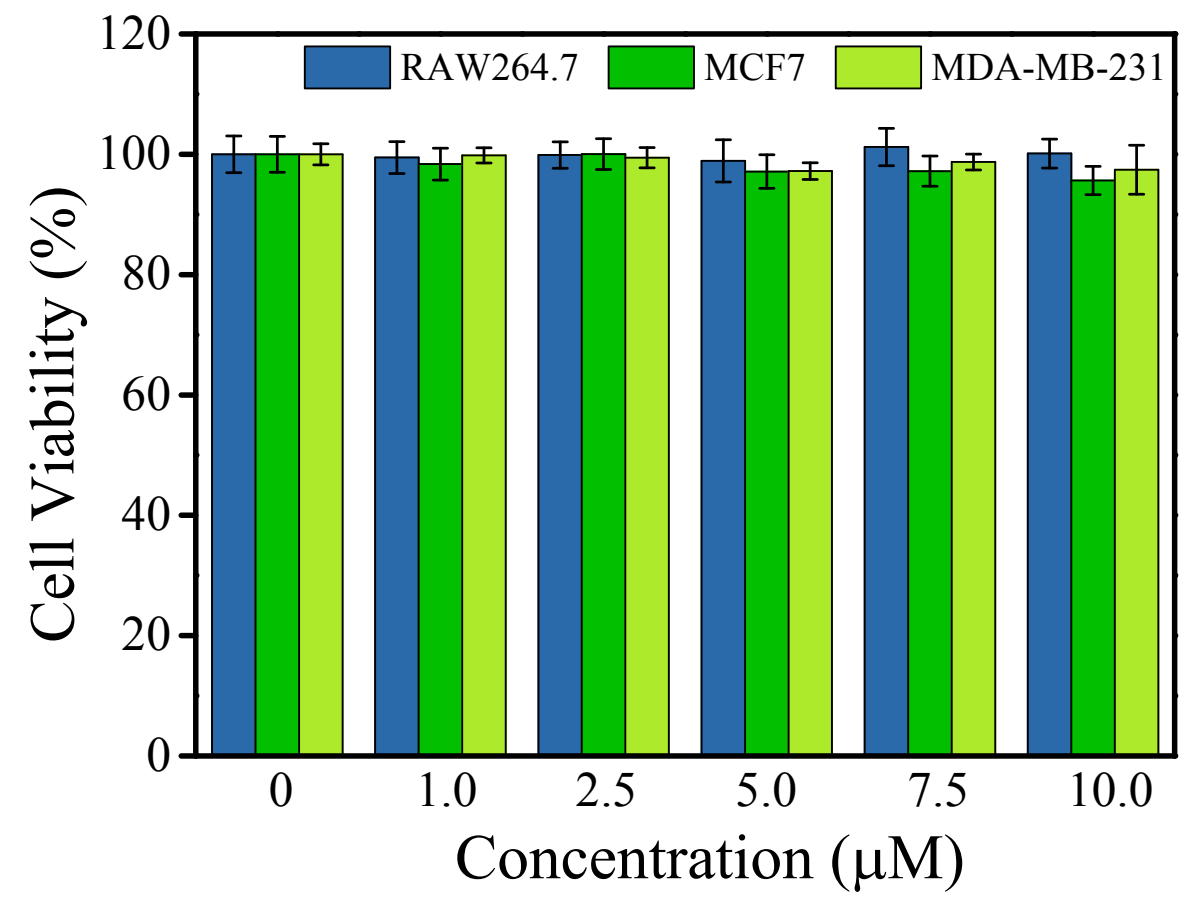

Figure S7 Cell viability values (\%) estimated by MTT assay in RAW264.7 macrophages, MCF7 cells and MDA-MB-231 lines, which were cultured in the presence of $0-10 \mu \mathrm{M}$ probe for $4 \mathrm{~h}$.

7. Additional cell imaging of probe for monitoring $\mathrm{H}_{2} \mathrm{O}_{2}$ 

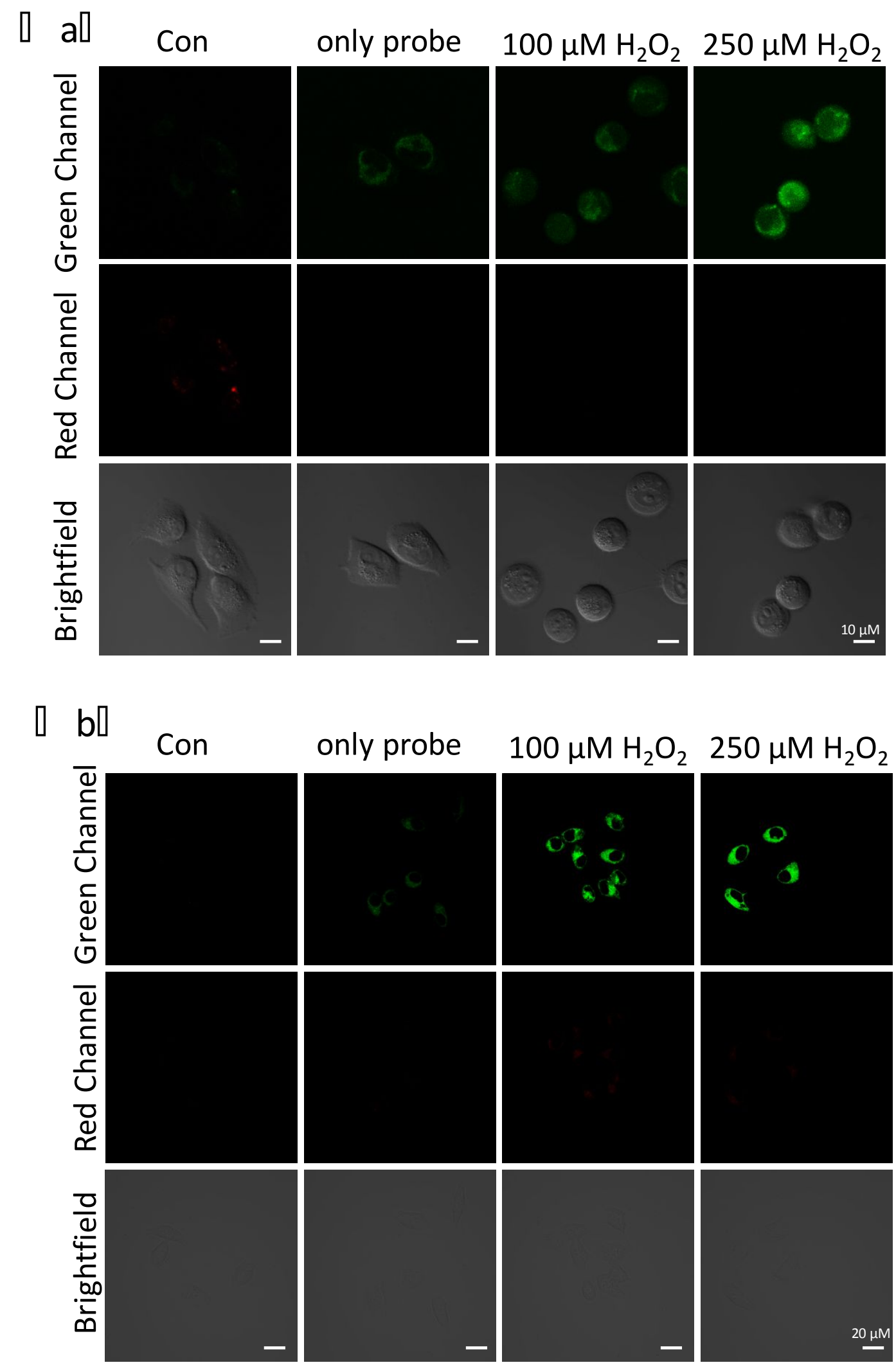

Figure S8 CLSM images of (a) HT1080 cells and (b) FADU cells loaded with $5 \mu \mathrm{M}$ probe, followed by incubation of $\mathrm{H}_{2} \mathrm{O}_{2}(0,100$, and $250 \mu \mathrm{M})$ for $30 \mathrm{~min}$. Green channel: $545 \pm 25 \mathrm{~nm}$; Red channel: $655 \pm 35 \mathrm{~nm}, \lambda_{\mathrm{ex}}=458 \mathrm{~nm}$. 


\section{References}

(1) Ren, M.; Deng, B.; Zhou, K.; Kong, X.; Wang, J. Y.; Lin, W. Anal. Chem. 2017, 89, 552555.

(2) Liu, J.; Liang, J.; Wu, C.; Zhao, Y. Anal. Chem. 2019, 91, 6902-6909.

(3) Reja, S. I.; Gupta, M.; Gupta, N.; Bhalla, V.; Ohri, P.; Kaur, G.; Kumar, M. Chem. Commun. 2017, 53, 3701-3704.

(4) Zhang, J.; Shi, L.; Li, Z.; Li, D.; Tian, X.; Zhang, C. Analyst 2019, 144, 3643-3648.

(5) Guo, H.; Chen, G.; Gao, M.; Wang, R.; Liu, Y.; Yu, F. Anal. Chem. 2019, 91, 12031210.

(6) Han, Z.; Liang, X.; Ren, X.; Shang, L.; Yin, Z. Chem. Asian J. 2016, 11, 818-822.

(7) Xiao, H.; Li, P.; Hu, X.; Shi, X.; Zhang, W.; Tang, B. Chem. Sci. 2016, 7, 6153-6159. 